\title{
KEPEMIMPINAN DAN BUDAYA ORGANISASI DALAM MEMPENGARUHI MOTIVASI SERTA DAMPAKNYA TERHADAP KINERJA PEGAWAI DINAS PEMADAM KEBAKARAN BEKASI
}

\section{(THE INFLUENCE OF LEADERSHIP AND ORGANIZATIONAL CULTURE TOWARD WORK MOTIVATION AND THAT IMPACT ON EMPLOYEE PERFORMANCE)}

\author{
Oleh: \\ Rochmad Fadjar Darmanto") ; Anik Ariyanti ${ }^{2)}$ \\ Sekolah Tinggi Ilmu Ekonomi IPWI Jakarta1,2) \\ rochmadfadjar@yahoo.co.id ${ }^{1)}$; ariyanti.anik@yahoo.co.id ${ }^{2}$ )
}

\begin{abstract}
This study aims to determine the effect of leadership and organizational culture on work motivation and that impact on employee performance of Dinas Pemada Kebakaran Kota Bekasi. The research type is explanatory research with a quantitative approach. The sample used was 100 people. Data collection and analysis are using Classical Assumption Test, Multiple Linear Regression, Determination Coefficient, Hypothesis Test, and Path Analysis. The results of the study prove that leadership and organizational culture influences work motivation; Leadership, Organizational Culture, and Work Motivation affect on performance but; Leadership and organizational culture through work motivation did not affect on performance.
\end{abstract}

Keywords: Leadership, organizational culture, work motivation and performance

\begin{abstract}
ABSTRAK
Penelitian bertujuan untuk mengetahui pengaruh kepemimpinan dan budaya organisasi terhadap motivasi kerja serta dampaknya terhadap kinerja pegawai Dinas Pemadam Kebakaran Kota Bekasi. Jenis penelitian explanatory research digunakan dengan pendekatan kuantitatif. Sampel yang digunakan adalah 100 orang. Pengumpulan dan analisis data dengan Uji Asumsi Klasik, Regresi Linier Berganda, Koefisien Determinasi, Uji Hipotesis, dan Analisis Jalur. Penelitian berhasil membuktikan bahwa Kepemimpinan dan Budaya berpengaruh nyata terhadap motivasi; Kepemimpinan, budaya organisasi dan motivasi kerja berpengaruh terhadap kinerja tetapi Kepemimpinan dan Budaya melalui motivasi kerja tidak berpengaruh nyata terhadap kinerja.
\end{abstract}

Kata kunci: Kepemimpinan, budaya organisasi, motivasi kerja dan kinerja 


\section{PENDAHULUAN}

Peranan seorang pemimpin sangat penting untuk mencapai tujuan organisasi terutama berkaitan dengan peningkatan kinerja. Seorang pemimpin adalah unsur yang menentukan pengembangan organisasi dan sangat menentukan berhasil tidaknya organisasi ditentukan oleh peranan pemimpin. Pemimpin organisasi selain mempunyai wewenang juga harus mempunyai kemampuan dan keterampilan untuk mempengaruhi orang lain (bawahan). Dengan kepemimpinannya, seorang pemimpin harus mampu berfikir dan bertindak melalui perilaku yang positif dalam upaya memberikan yang terbaik untuk organisasi. Pemimpin mempunyai peran vital dalam upaya menggerakkan bawahan dan mempunyai tanggung jawab yang tinggi dalam mencapai tujuan organisasi.

Dinas Pemadam Kebakaran Kota Bekasi mempunyai pegawai yang memiliki latar belakang pendidikan yang berbedabeda dan untuk mencapai tujuan bersama diperlukan seorang pemimpin yang mempunyai kompetensi, yang membawa membawa pengaruh terhadap kelangsungan dan perkembangan dinas.

Seorang pemimpin selain mampu memberikan pengaruh yang positif terhadap semangat bawahan, juga harus mampu meningkatkan kinerjanya. Pimpinan Dinas Pemadam Kebakaran Kota Bekasi harus memahami pegawai yang dimiliki saat ini maupun ke depannya. Selain itu budaya organisasi yang kuat dan kokoh perlu juga dikembangkan dengan harapan mempererat individu yang ada sehingga dapat membentuk sikap dan perilaku pegawai yang semakin baik. Kepemimpinan yang baik dapat mendorong kinerja karyawan (Sumarni, 2011). Selain itu kepemimpinan dan budaya organisasi, keduanya memberikan pengaruh terhadap peningkatan kinerja pegawai yang cukup besar yaitu sebesar 70,8\% (Setiawan, 2015).

Faktor lain yang mendukung peningkatan kinerja, selain peran kepemimpinan dan budaya organisasi yang kuat dan kokoh, adalah motivasi kerja pegawai. Motivasi kerja akan dicapai bila ada kemauan dari diri sendiri dan mendapat dorongan dari pihak lain. Motivasi kerja adalah proses dimana kebutuhan mendorong seseorang untuk melakukan serangkaian kegiatan yang mengarah tercapainya tujuan tertentu.

Setiap organisasi mempunyai harapan yang besar agar pegawai dapat meningkatkan kinerja yang terbaik. Kinerja merupakan kesuksesan seseorang dalam melaksanakan suatu pekerjaan. Dengan demikian untuk meningkatkan kinerja pegawai, Dinas Pemadam Kebakaran Kota Bekasi harus mampu mengukur dan meningkatkan peranan kepemimpinan, kekuatan budaya organisasi dan tingkat motivasi kerja pegawai.

\section{TUJUAN PENELITIAN}

Penelitian bertujuan mengetahui dan atau menganalisis ada tidaknya pengaruh kepemimpinan dan budaya organisasi terhadap motivasi kerja pegawai; kepemimpinan, budaya organisasi dan motivasi terhadap kinerja pegawai; kepemimpinan dan budaya organisasi terhadap kinerja melalui motivasi kerja pegawai Dinas Pemadam Kebakaran Kota Bekasi.

\section{TELAAH LITERATUR DAN} PENGEMBANGAN HIPOTESIS

\section{Kepemimpinan}

Menurut

kepemimpinan

mempengaruhi

Gary Yukl
adalah
orang lain
proses untuk 
melaksanakan tugas sesuai yang diharapkan. Kepemimpinan adalah proses memfasilitasi individu atau sekelompok individu guna mencapai tujuan.

Kepemimpinan (leadership) adalah dapat juga diartika sebagai proses mempengaruhi dengan memberi contoh kepada pihal lain lewat komunikasi dalam upaya mencapai tujuan. Keseluruhan tindakan guna mempengaruhi serta menggiatkan orang dalam usaha bersama untuk mencapai tujuan (Rivai, 2004), atau proses pemberian alur kerja yang mudah pada pekerjaan orang lain secara terorganisir dalam organisasi formal guna mencapai tujuan yang telah ditetapkan (Rivai, 2004).

T Hani Handoko dan Reksohadiprojo (2003) mengutip pendapat Davis bahwa terdapat 10 faktor yang mempengaruhi kesuksesan kepemimpinan adalah: 1) kecerdasan, 2) kedewasaan, 3) motivasi diri, 4) sikap-sikap hubungan manusiawi, 5) memiliki pengaruh yang kuat, 6) memiliki pola hubungan yang baik, 7) memiliki sifat-sifat tertentu, 8) memiliki kedudukan atau jabatan, 9) mampu berinteraksi, dan 10) mampu memberdayakan.

Pada sebuah penelitian di PDAM Tirta Moedal Semarang, terdapat temuan bahwa kepemimpinan berpengaruh terhadap kinerja karyawan tetapi sebaliknya, tidak terdapat pengaruh budaya organisasi terhadap kinerja karyawan (Sumarni, 2011). Penelitian lain mengungkap bahwa kepemimpinan dan budaya organisasi secara nyata memberikan pengaruh terhadap kinerja pegawai dimana budaya organisasi pengaruhnya lebih dominan (Setiawan, 2015).

\section{Budaya Organisasi}

Budaya organisasi adalah seperangkat nilai yang diikuti dan dianut sebagai pedoman kerja bagi seluruh anggota organisasi sehingga menjadi ciri khas yang membedakan dengan organisasi lain. Budaya organisasi mengarah pada perilaku yang dimiliki oleh anggota organsiasi yang sesuai dengan budaya yang berlaku sehingga dapat diterima oleh lingkunganya.

Budaya organisasi adalah karakteristik yang harus dijunjung tinggi oleh organisasi dan harus menjadi panutan organisasi sebagai perbedaan satu organisasi dengan organisasi lain. Budaya organisasi merupakan nilai dan norma-norma perilaku yang diterima dan dipahami secara keseluruhan oleh anggota organisasi sebagai dasar aturan yang diterapkan dalam organisasi (Ahmad Handy, 2017).

Terdapat 7 (tujuh) karakteristik primer budaya organisasi meliputi: inovasi dan pengambilan resiko, perhatian ke hal yang rinci, orientasi hasil, orientasi orang, orientasi tim, keagresifan, dan kemantapan. Secara alami budaya organisasi sukar untuk dipahami, tidak berwujud, implisit dan dianggap biasa saja. Setiap perusahaan memiliki tipe budaya organisasi, sebuah organisasi atau perusahaan mungkin dapat memiliki budaya organisasi dominan yang sama, namun perusahaan memiliki keyakinan normatif dan karakteristik budaya organisasi yang lain (Robbins dan Judge, 2013).

\section{Motivasi Kerja}

Menurut Bangun (2012) motivasi berasal dari kata motif (motive), yang berarti dorongan atau suatu kondisi yang mendorong atau menjadi sebab seseorang melakukan suatu perbuatan atau kegiatan, yang berlangsung secara sadar.

Maslow (dalam Malayu SP Hasibuan, 2017) mengemukakan bahwa motivasi adalah dorongan yang timbul pada diri seseorang untuk memenuhi kebutuhannya. Maslow dalam Teori 
Hierarki Kabutuhan menyebutkan bahwa dalam diri seseorang terdapat lima tingkatan kebutuhan yaitu kebutuhan fisiologis, kebutuhan rasa aman, kebutuhan sosial, kebutuhan penghargaan dan kebutuhan aktualisasi diri.

Motivasi kerja bertujuan meningkatkan moral kepuasan kerja karyawan, menambah produktivitas kerja, mempertahankan karyawan, mendorong kedisiplinan, mengefektifkan pemenuhan kebutuhan karyawan, menciptakan suasana kerja yang nyaman, menumbuhkan hubungan kerja yang baik antar berbagai pihak, meningkatkan loyalitas kepada organisasi, menumbuhkan kreativitas pegawai, mendorong partisipasi pegawai, meningkatkan kesejahteraan, mempertinggi rasa tanggung jawab karyawan terhadap tugas dan meningkatkan efisiensi (Malayu SP Hasibuan, 2017).

Sabtarini (2016) dalam penelitiannya menyebutkan bahwa ada pengaruh kepemimpinan terhadap motivasi kerja dengan arah positif, ada pengaruh budaya kerja terhadap motivasi kerja dengan arah positif dan ada pengaruh motivasi kerja terhadap kinerja dengan arah positif.

\section{Kinerja}

Menurut Torang (2016) kinerja merupakan kuantitas dan kualitas hasil kerja individu atau kelompok dalam melaksanakan tugas pokok dan fungsi sesuai norma, standar operasional prosedur, kriteria dan ukuran tertentu yang telah ditetapkan sebelumnya atau yang berlaku dalam organisasi.

Menurut Edison (2016) kinerja adalah hasil dari suatu proses yang mengacu dan diukur selama periode waktu tertentu berdasarkan ketentuan atau kesepakatan yang telah ditetapkan sebelumnya. Kinerja menjadi cerminan kemampuan dan keterampilannya dalam pekerjaan tertentu yang akan berdampak pada reward dari perusahaan.

Menurut Edy Sutrisno (2016) kinerja merupakan kesuksesan seseorang dalam melaksanakan tugas, hasil kerja yang dapat dicapai oleh seseorang atau sekelompok orang dalam suatu organisasi sesuai dengan wewenang dan tanggung jawab masing-masing atau tentang bagaimana seseorang diharapkan dapat berfungsi dan berperilaku sesuai dengan tugas yang telah dibebankan kepadanya serta kuantitas, kualitas dan waktu yang digunakan dalam menjalankan tugas. Kinerja dipengaruhi oleh faktor intrinsik yaitu personal individu dan faktor ekstrinsik yaitu sistem, tim, situasional dan konflik (Mangkuprawira, 2007).

Secara langsung kepemimpinan mempengaruhi motivasi kerja, budaya organisasi mempengaruhi motivasi kerja. Secara langsung kepemimpinan mempengaruhi kinerja dan budaya organisasi mempengaruhi kinerja. Motivasi kerja secara langsung mempengaruhi kinerja. Secara tidak langsung Kepemimpinan melalui motivasi kerja berpengaruh terhadap kinerja dan budaya organisasi melalui motivasi kerja berpengaruh terhadap kinerja.

Beberapa penjelasan pengertian di atas memberikan gambaran kerangka pemikiran dan hipotesis, sebagai berikut:

Gambar 1

Kerangka Pemikiran

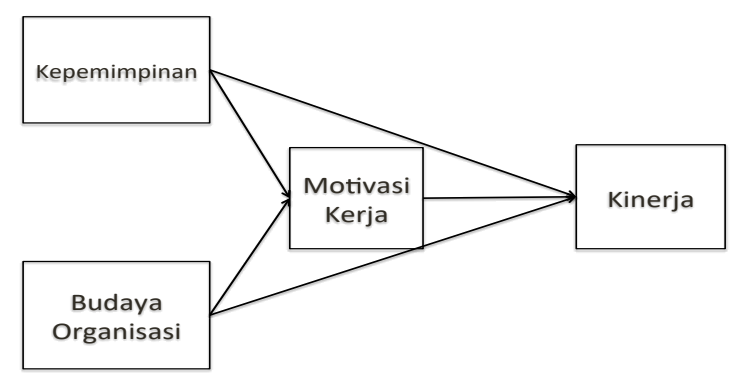

Sumber: data diolah, 2019 


\section{Hipotesis}

berikut:

Hipotesis penelitian ini adalah sebagai

H1: Kepemimpinan berpengaruh nyata terhadap motivasi kerja.

$\mathrm{H} 2$ : Budaya organisasi berpengaruh nyata terhadap motivasi kerja.

H3: Kepemimpinan berpengaruh nyata terhadap kinerja.

H4: Budaya organisasi berpengaruh nyata terhadap kinerja.

H5: Motivasi kerja berpengaruh nyata terhadap kinerja.

H6: Kepemimpian melalui motivasi kerja berpengaruh terhadap nyata kinerja.

H7: Budaya organisasi melalui motivasi kerja berpengaruh nyata terhadap kinerja.

\section{METODE PENELITIAN}

\section{Tempat dan Waktu Penelitian}

Penelitian dilakukan dengan di Dinas Pemadam Kebakaran Kota Bekasi, yang beralamat lengkap di Jalan Jenderal Ahmad Yani Nomor 01 Kota Bekasi. Penelitian dilakukan selama empat bulan yaitu bulan Januari - April 2019.

\section{Populasi dan Sampel}

Populasi penelitian adalah pegawai di Dinas Pemadam Kebakaran Kota Bekasi yang berjumlah sebanyak 400 orang. Sampel penelitian ini yaitu sebesar 100 orang. Metode sampling menggunakan purposive sampling dengan persyaratan pegawai yang sudah memiliki masa kerja minimal 2 tahun dan usia antara 30 sampai dengan 55 tahun.

\section{Desain Penelitian}

Jenis penelitian ini explanatory research, yaitu jenis penelitian yang bertujuan menjelaskan hubungan antara variabel-variabel serta menguji hipotesa yang ada. Pendekatan penelitian yang digunakan adalah pendekatan kuantitatif. Variabel dalam penelitian ini meliputi: variabel independen atau variabel bebas atau variabel anteseden yaitu variabel yang mempengaruhi variabel dependen berupa variabel kepemimpinan dan budaya oganisasi. Variabel dependen atau variabel terikat atau variabel utama yaitu variabel yang dipengaruhi variabel bebas berupa variabel kinerja. Variabel intervening adalah variabel yang secara teoritis dipengaruhi variabel independen sekaligus mempengruhi variabel dependen berupa variabel motivasi kerja (Sugiyono, 2014).

\section{Definisi Operasional}

a. Kepemimpinan merupakan proses mempengaruhi orang lain untuk memahami dan menyetujui apa yang dibutuhkan dalam melaksanakan tugas dan bagaimana melaksanakan tugas itu, serta proses untuk memfasilitasi upaya individu dan kolektif guna mencapai tujuan bersama (Gary Yukl, 2015).

b. Budaya organisasi merupakan karakteristik yang harus dijunjung tinggi di dalam organisasi dan harus menjadi panutan organisasi sebagai perbedaan satu organisasi dengan organisasi lain (Ahmad Handy, 2017).

c. Motivasi Kerja merupakan bentuk rangsangan keinginan dan pemberian daya penggerak yang bisa menciptakan kegairahan kerja seseorang agar mereka mau bekerja sama, bekerja efektif dan berintegrasi dengan segala upayanya untuk mencapai kepuasan (Hasibuan, 2017).

d. Kinerja merupakan hasil dari suatu proses yang mengacu dan diukur selama periode waktu tertentu berdasarkan ketentuan atau kesepakatan yang telah ditetapkan sebelumnya. Kinerja menjadi 
cerminan kemampuan dan keterampilan dalam pekerjaan tertentu yang akan berdampak pada reward dari perusahaan (Edison, 2016).

\section{Pengumpulan Data}

Penelitian ini menggunakan data primer dan sekunder. Data primer yaitu data yang berasal langsung dari responden sesuai dengan permasalahan yaitu melalui observasi, komunikasi dan menyebarkan kuesioner kepada para pegawai Dinas Pemadam Kebakaran Kota Bekasi. Data sekunder yaitu sumber-sumber informasi dari buku, jurnal, internet dan artikel perndukung.

\section{Uji Instrumen Penelitian}

Untuk mengetahui tingkat kevalidan dan kehandalan data penelitian digunakan uji validitas dan reliabilitas data. Pengujian validitas dilakukan dengan pengambilan keputusan berdasarkan nilai Corrected Item-Total Correlation dimana nilai kritisnya dalah 0,3 sehingga jika Corrected Item-Total Correlation $>0,3$ maka instrumen dinyatakan valid dan demikian pula sebaliknya. Seluruh pertanyaan Kepemimpinan (X1), Budaya Organisasi (X2), Motivasi (Y) dan Kinerja (Z) dikatakan valid karena nilai Corrected Item-Total Correlation masing-masing item pada tiap variabel $>0,3$, maka dapat diartikan bahwa seluruh instrumen layak digunakan sebagai alat ukur penelitian. Nilai Cronbach Alpha semua variabel diketahui $\geq 0,60$, artinya bahwa seluruh instrumen pada masing-masing variabel telah reliabel.

\section{Metode Analisis}

Analisis penelitian menggunakan Uji Asumsi Klasik dengan uji normalitas, multikolinieritas, dan heteroskedastisitas, Regresi Linier Berganda, Koefisien
Determinasi, Uji Hipotesis dan Analisis Jalur (Path Analysis) dengan program SPSS (Statistical Program for Social Science) versi 16 for Windows.

\section{HASIL PENELITIAN DAN \\ PEMBAHASAN \\ Uji Asumsi Klasik}

Pada uji normalitas diketahui grafik PPlot menunjukkan tingkat normalitas data. Uji multikolinieritas diketahui nilai Tolerance masing-masing variabel indenpenden sebesar 0,440 (X1), 0,475 (X2) dan $0,568(\mathrm{Y})>10 \%$ dan Variance Inflation Factor (VIF) masing-masing variabel independen 2,274, 2,106 dan 1,760< VIF = 10, sehingga antara variabel independen tidak terjadi multikolinieritas. Pada uji heteroskedastisitas dan dari grafik tergambar bahwa tidak ada pola yang jelas dan titik-titik menyebar di bawah serta di atas sumbu $Y$, sehingga tidak terjadi heteroskedastisitas.

\section{Regresi Linier Berganda}

Hasil uji regresi dapat diketahui seperti pada tabel berikut:

Tabel 1

Uji Regresi Berganda 1

\begin{tabular}{|l|r|r|r|}
\hline \multirow{2}{*}{ Model } & \multicolumn{1}{|c|}{$\begin{array}{c}\text { Standardized } \\
\text { Coefficients }\end{array}$} & & \\
\cline { 2 - 3 } & \multicolumn{1}{|c|}{ Beta } & \multicolumn{1}{c|}{$\mathrm{t}$} & \multicolumn{1}{c|}{ Sig. } \\
\hline 1 (Constant) & & 6.160 & .000 \\
Kepemimpinan & .423 & 3.943 & .000 \\
Budaya Organisasi & .288 & 2.687 & .008 \\
\hline
\end{tabular}

Sumber: Output SPSS, 2019

Tabel 1 tersebut menunjukkan model persamaan regresi: $\mathrm{Y}=0,423 \mathrm{X} 1+0,288 \mathrm{X} 2$. Model tersebut menjelaskan bahwa kepemimpinan mempunyai pengaruh sebesar 0,423 terhadap motivasi kerja. Budaya organisasi mempunyai pengaruh sebesar 0,288 terhadap motivasi kerja. 
Tabel 2

Uji Regresi Berganda 2

\begin{tabular}{|c|c|c|c|}
\hline & $\begin{array}{c}\text { Standardized } \\
\text { Coefficients } \\
\end{array}$ & & \\
\hline Model & Beta & $\mathrm{t}$ & Sig. \\
\hline 1 (Constant) & & 2.731 & .008 \\
\hline Kepemimpinan & .214 & 2.517 & .013 \\
\hline $\begin{array}{l}\text { Budaya } \\
\text { Organisasi }\end{array}$ & .416 & 5.091 & .000 \\
\hline Motivasi Kerja & .327 & 4.380 & .000 \\
\hline
\end{tabular}

Sumber: Output SPSS, 2019

Tabel 2 di atas menghasilkan model persamaan regresi ganda $Z=0,214 \mathrm{X} 1+$ 0,416X2 + 0,327Y. Model tersebut menjelaskan bahwa kepemimpinan berpengaruh terhadap kinerja yang ditunjukkan oleh koefisien $\beta=0,214$. Budaya organisasi berpengaruh terhadap kinerja yang ditunjukkan oleh koefisien $\beta=$ 0,416 dan motivasi kerja berpengaruh terhadap kinerja oleh koefisien $\beta=0,327$.

\section{Koefisien Determinasi}

Besaran nilai koefisien determinasi ditunjukkan oleh nilai Adjusted R Square sebesar 0,686 artinya kepemimpinan, budaya organisasi dan motivasi kerja mempunyai kontribusi sebesar 68,6\% terhadap kinerja dan sisanya $31,4 \%$ dijelaskan faktor lain.

\section{Analisis Jalur (Path Analysis)}

Penjelasan dari analisis jalur adalah sebagai berikut:

1. Analisis Jalur 1

Hasil regresi pada Tabel 1 menunjukkan bahwa nilai signifikansi dari kepemimpinan sebesar 0,000 dan budaya organisasi sebesar 0,008 < 0,05. Artinya kepemimpinan dan budaya organisasi berpengaruh nyata terhadap motivasi kerja. Nilai $R$ Adjusted Square adalah sebesar 0,420 sehingga kontribusi kepemimpinan dan budaya organisasi terhadap motivasi kerja sebesar $42 \%$ sisanya $58 \%$ kontribusi dari variabel lain. Nilai $\varepsilon 1$ diperoleh sebesar $\sqrt{ } 1-0,420=0,762$.

2. Analisis Jalur 2

Hasil regresi pada Tabel 2 dapat diketahui bahwa nilai signifikansi kepemimpinan sebesar 0,013, budaya organisasi sebesar 0,000 dan motivasi kerja sebesar 0,000 < 0,05. Artinya kepemimpinan, budaya organisasi dan motivasi kerja berpengaruh nyata terhadap kinerja. Nilai $\mathrm{R}$ Adjusted Square sebesar 0,686 sehingga kontribusi kepemimpinan, budaya organisasi dan motivasi kerja terhadap kinerja sebesar $68,6 \%$ sisanya $31,4 \%$ dari kontribusi variabel lain. Nilai $\varepsilon 2$ diperoleh sebesar $\sqrt{1}-0,686=0,560$.

Diagram jalur yang dihasilkan adalah sebagai berikut:

Gambar 2

Hasil Analisis Jalur

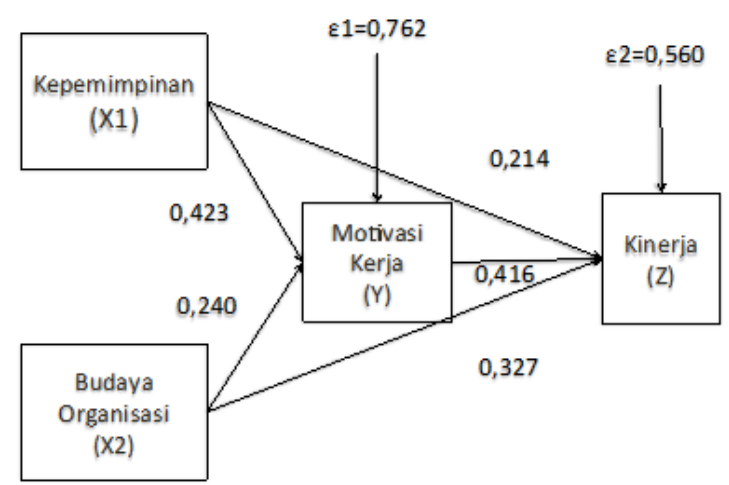

Sumber: data diolah, 2019

\section{Pengujian Hipotesis}

Hasil analisis yang dilakukan menunjukkan bahwa

a. Nilai probabilitas kepemimpinan terhadap motivasi kerja adalah sebesar Sig. $=0,000$. Jika dibandingkan maka lebih kecil daripada taraf uji penelitian $\alpha=0,05$ dengan koefisien $\beta=0,423$; sehingga kepemimpinan berpengaruh 
terhadap motivasi kerja yang nilainya positif.

b. Nilai probabilitas budaya organisasi terhadap motivasi kerja adalah sebesar Sig. $=0,008$. Jika dibandingkan maka lebih kecil daripada taraf uji penelitian $\alpha=0,05$ dengan koefisien $\beta=0,240$; sehingga budaya organisasi berpengaruh terhadap motivasi kerja dengan nilai positif.

c. Nilai probabilitas kepemimpinan terhadap kinerja adalah sebesar Sig. = 0,013. Jika dibandingkan maka lebih kecil daripada taraf uji penelitian $\alpha=$ 0,05 dengan koefisien $\beta=0,214$; sehingga kepemimpinan berpengaruh terhadap kinerja dengan nilai positif.

d. Nilai probabilitas budaya organisasi terhadap kinerja adalah sebesar Sig. = 0,000. Jika dibandingkan maka lebih kecil daripada taraf uji penelitian $\alpha=$ 0,05 dengan koefisien $\beta=0,327$; sehingga budaya organisasi berpengaruh terhadap kinerja dengan nilai positif.

e. Nilai probabilitas motivasi kerja terhadap kinerja adalah sebesar Sig. = 0,000. Jika dibandingkan maka lebih kecil daripada taraf uji penelitian $\alpha=$ 0,05 dengan koefisien $\beta=0,416$; sehingga motivasi kerja berpengaruh terhadap kinerja dengan nilai positif.

f. Pada hasil perhitungan diketahui pengaruh tidak langsung variabel kepemimpinan terhadap kinerja melalui motivasi kerja adalah sebesar 0,176 yaitu hasil perkalian pengaruh kepemimpinan terhadap motivasi $(0,423)$ dan pengaruh motivasi terhadap kinerja $(0,416)$. Pengaruh langsung kepemimpinan terhadap kinerja atau 0,214 lebih besar daripada pengaruh tidak langsung sebesar 0,176 . Sehingga dapat disimpulkan bahwa tidak ada pengaruh kepemimpinan melalui motivasi kerja terhadap kinerja.

g. Pengaruh tidak langsung budaya organisasi terhadap kinerja melalui motivasi kerja adalah sebesar 0,099 yang merupakan perkalian dari pengaruh budaya terhadap motivasi $(0,240)$ dengan pengaruh motivasi terhadap kinerja $(0,416)$. Pengaruh langsung budaya organisasi terhadap kinerja yang sebesar 0,327 memiliki nilai yang lebih besar daripada pengaruh tidak langsung yaotu sebesar 0,099. Hal ini dapat dimaknai bahwa tidak ada pengaruh budaya organisasi terhadap kinerja melalui motivasi kerja.

\section{Pembahasan \\ Pengaruh Langsung}

Kepemimpinan yang ada di Dinas Pemadam Kebakaran Kota Bekasi tergolong cukup baik dan mempunyai pengaruh signifikan terhadap motivasi kerja, yaitu sebesar 0,423 pada nilai sig 0,000 < 0,05 artinya H1 diterima. Budaya organisasi pada Dinas Pemadam Kebakaran Kota Bekasi tergolong cukup baik dan mempunyai pengaruh signifikan terhadap motivasi kerja, yaitu sebesar 0,288 pada sig 0,000 < 0,05 artinya H2 diterima. Kepemimpinan mempunyai pengaruh signifikan terhadap kinerja, yaitu sebesar 0,214 pada sig 0,013<0,05 sehingga H3 diterima. Budaya organisasi mempunyai pengaruh signifikan terhadap kinerja, yaitu sebesar 0,416 pada sig 0,000 $<0,05$ sehingga H4 diterima. Motivasi kerja mempunyai pengaruh signifikan terhadap kinerja yaitu sebesar 0,327 pada sig 0,000 < 0,05 sehingga H5 diterima.

\section{Pengaruh Tidak Langsung}

Pengaruh kepemimpinan melalui motivasi kerja terhadap kinerja pegawai adalah sebesar 0,176 atau lebih kecil 
daripada pengaruh langsungnya yaitu sebesar 0,214. Hal ini mengindikasikan tidak adanya pengaruh kepemimpinan melalui motivasi kerja terhadap kinerja sehingga H7 ditolak. Pengaruh budaya organisasi melalui motivasi kerja terhadap kinerja yaitu sebesar 0,099 atau lebih kecil daripada pengaruh langsungnya yaitu sebesar 0,327. Hal ini memberikan arti bahwa tidak ada pengaruh budaya organisasi melalui motivasi kerja terhadap kinerja sehingga H7 ditolak.

\section{KESIMPULAN}

a. Kepemimpinan berpengaruh nyata terhadap motivasi kerja pegawai Dinas Pemadam Kebakaran Kota Bekasi.

b. Budaya organisasi mempunyai pengaruh nyata terhadap motivasi kerja pegawai Dinas Pemadam Kebakaran Kota Bekasi.

c. Kepemimpinan berpengaruh nyata terhadap kinerja pegawai Dinas Pemadam Kebakaran Kota Bekasi.

d. Budaya organisasi berpengaruh nyata terhadap kinerja pegawai Dinas Pemadam Kebakaran Kota Bekasi.

e. Motivasi kerja mempunyai pengaruh nyata terhadap kinerja pegawai Dinas Pemadam Kebakaran Kota Bekasi.

f. Tidak ada pengaruh kepemimpinan terhadap kinerja melalui motivasi kerja pegawai Dinas Pemadam Kebakaran Kota Bekasi.

g. Tidak ada pengaruh budaya organisasi terhadap kinerja melalui motivasi kerja pegawai Dinas Pemadam Kebakaran Kota Bekasi.

\section{SARAN}

a. Peranan kepemimpinan di lingkungan Dinas diharapkan mampu menjadi media untuk mempengaruhi pegawai agar bekerja sesuai dengan Tupoksi. Kepemimpinan yang ideal akan berpengaruh terhadap motivasi kerja maupun kinerja pegawai Dinas Pemadam Kebakaran Kota Bekasi.

b. Budaya organisasi harus dipahami oleh para pegawai dan pimpinan harus memberikan pengetahuan tentang budaya di lingkungan Dinas yang tidak sama dengan budaya di tempat lain. Pemahaman yang baik tentang budaya organisasi berpengaruh terhadap motivasi kerja dan kinerja pegawai Dinas Pemadam Kebakaran Kota Bekasi.

c. Motivasi kerja pegawai harus terusmenerus ditingkatkan yaitu dengan memberikan dorongan semangat melalui pemberian kebutuhan pegawai baik secara finansial maupun nonfinansial.

d. Kinerja pegawai Dinas Pemadam Kebakaran Kota Bekasi hendaknya tidak hanya diukur dari faktor kepemimpinan, budaya organisasi dan motivasi kerja tetapi harus diukur dari faktor lain.

e. Upaya peningkatan kinerja pegawai dengan memberikan motivasi kerja dan menumbuhkan komitmen organisasi.

\section{DAFTAR PUSTAKA}

Bangun, Wilson. (2012). Manajemen Sumber Daya Manusia. Jakarta: Erlangga.

Edison. (2016). Manajemen Sumber Daya Manusia. Bandung: Alfabeta.

Handy, Ahmad. (2017). [LENGKAP] Fungsi, Contoh dan Pengertian Budaya Organisasi. Education.handy.co.id. Diposting pada 2 Mei 2017.

Handoko, T Hani dan Reksahadiprojo (2013). Manajemen Sumber Daya Manusia (Cetakan Pertama). Yogyakarta: Graha Ilmu. 
Hasibuan, Malayu S.P. (2017). Manajemen Sumber Daya Manusia. Edisi Revisi. Jakarta: Bumi Aksara.

Kusumaningsih, Sabtarini. (2016). Pengaruh Kepemimpinan dan Budaya Kerja terhadap Motivasi Kerja Berdampak Kinerja (Studi pada Dosen di Kopertis Wilayah VI Kota Semarang). Skripsi. Semarang: STIE AKA Semarang.

Mangkuprawira. TB.S dan A.V. Hubeis. (2007). Manajemen Mutu Sumber Daya Manusia. Bogor; Ghalia Indonesia.

Robbins. P. Stephen and Judge. (2013). Organizational Behavior. 15th edition. Boston: Pearson.

Setiawan, Heru. (2015). Pengaruh Kepemimpinan dan Budaya Organisasi terhadap Kinerja Pegawai pada Badan Perencanaan Pembangunan Daerah (BAPPEDA) Kota Bandung. Skripsi. Bandung: Fakultas Ekonomi Unpas.

Sugiyono. (2014). Metode Penelitian Kuantitatif, Kualitatif dan $R$ \& $D$. Bandung: Alfabeta
Sumarni, Dede. (2011). Pengaruh Kepemimpinan dan Budaya Organisasi terhadap Kinerja Karyawan (Studi Kasus pada PDAM Tirta Moedal Semarang). Skripsi. Semarang: Fakultas Ekonomi UNS.

Sutrisno, Edy. (2016). Manajemen Sumber Daya Manusia. Jakarta: Prenada Media Group.

Torang, Syamsir. (2013). Organisasi dan Manajemen: Perilaku, Struktur, Budaya \& Perubahan Organisasi. Bandung: Alfabeta.

Yukl, Gary. (2015). Kepemimpinan dalam Organisasi (Leadership in Organization), Edisi Ketujuh. Jakarta: PT Indeks.

Veithzal, Rivai. (2004). Manajemen Sumber Daya Manusia untuk Perusahaan: Dari Teori ke Praktik. Edisi Ketiga. Depok: PT Grafindo Persada. 